\title{
KLEUR EN KLEURPERSEPSIE: 'N OORSIG VAN MODERNE EN ANTIEKE BESKOUINGE *
}

\author{
$R$ Meyer (UNISA)
}

\begin{abstract}
Die bestudering van kleurbeskrywing in die antieke Oudheid was lank in omstredenheid gehul. Aanvanklik was hierdie ongelukkige situasie die direkte uitvloeisel van moderne opvattings en wetenskaplike bevindings waarmee kleurterminologie in die Griekse en Romeinse letterkunde ontleed en verklaar is. Aldus het wanpersepsies ontstaan, wat sommige van die antieke uitbeeldings as 'foutief' of 'gebrekkig' afgemaak het. Benewens hierdie problematiese beskouinge, fokus hierdie artikel ook op navorsing wat mettertyd ontwikkel is om ' $\mathrm{n}$ sensitiewer beoordeling van die implikasies van antieke kleurterminologie daar te stel. Waar so 'n sinvolle ontleding ontbreek, kan die moderne leser nie daarop aanspraak maak dat hy / sy die volle impak van kleurbeskrywing in die Griekse en Romeinse poësie waardeer of verstaan nie.
\end{abstract}

Trefwoorde: kleurterminologie; kleurbeskrywing; kleurpersepsie; sensitiwiteit; interpretasie

Ons leef in 'n wêreld van natuurlike kleur. Soms kan die kleur asembenewend wees, met tye kom dit vervelig en vaal voor en al te dikwels word dit skaars raakgesien. Alhoewel Ruscillo (2007:371) die konsep van kleur as abstrak en vaag ('tenuous') beskou, deurdring kleur tog elke aspek van ons lewens. ${ }^{1}$ Dit word selfs

* Hiermee dank aan Akroterion se anonieme beoordelaars vir sinvolle voorstelle. Opregte waardering ook aan professor Jo-Marie Claassen (Stellenbosch) vir waardevolle hulp en leiding.

1 Helen Keller 1910:105 het doelbewus die belewenis van kleur deel van haar bestaanswêreld gemaak:

'I understand how scarlet can differ from crimson because I know that the smell of an orange is not the smell of a grapefruit. I can also conceive that colors have shades and guess what shades are. In smell and taste there are varieties not broad enough to be fundamental; so I call them shades ... The force of association drives me to say that white is exalted and pure, green is exuberant, red suggests love or shame or strength. Without the color or its equivalent, life to me would be dark, barren, a vast blackness.

Thus, through an inner law of completeness my thoughts are not permitted to remain colorless. It strains my mind to separate color and sound from objects. Since my education began I have always had things described to me with their colors and sounds, by one with keen senses and a fine feeling for the significant. Therefore, I habitually think of things as colored and resonate ... the unity of the world demands that colors be kept in it whether I have cognizance of it or not. Rather than be shut out, I take part in it by discussing it, happy in the happiness of those near me who gaze at the lovely hues of the sunset or the rainbow'. 
aangepas om in ons individuele, maar ook sosiale en kulturele behoeftes, te voldoen: 'Colour is a cultural matter ...', volgens Eco (1996:152, met verwysing na Sahlins). ${ }^{2}$ In enige moderne samelewing word kleur op uiteenlopende, unieke wyses beleef en aangewend, wat nie alleen van individu tot individu nie, maar ook van gemeenskap tot gemeenskap verskil. Pastoureau (2001:8) identifiseer kleur as 'n komplekse sosiale konsep: '... [it] resists generalization, and, indeed analysis itself ... Many authors search for the universal or archetypal truths they imagine reside in colour, but colour is first and foremost a social phenomenon. There is no transcultural truth to colour perception'. Kleur word vergestalt in die kunste, in die versiering van argitektektoniese strukture, in persoonlike voorkoms en in sosiale verkeer. ${ }^{3}$ Laasgenoemde behels ook die aanwending van taal, waarvolgens elke taalgemeenskap 'n eie wêreldbeskouing handhaaf. ${ }^{4}$

Sou die kleur-terminologie van verskillende tale vergelyk word, is dit duidelik dat dit op verskillende wyses ontleed, geklassifiseer en beoordeel moet word. Eentaal-sprekers aanvaar dikwels dat hul eie kleursisteme deursigtig en verstaanbaar is, maar, gekonfrontreer met 'n alternatiewe sisteem, kom 'die ander' dikwels verwarrend en selfs onverklaarbaar voor. In 'n veeltalige gemeenskap is kleurpersepsie uiteraard minder rigied.

\section{Moderne kleurbeskrywing ${ }^{5}$}

Om die interpretasie van kleur te vergemaklik en aanvaarbaar te maak, moet enige beskrywing van kleur duidelik en akkuraat oorgedra word. Kleur moet ook

2 Van Leeuwen 2011:15-19 bied 'n moderne beskouing van die verskillende psigologiese betekenisse wat aan kleure gekoppel kan word: 'The same colour can express many different meanings and the same meaning can be expressed by many different colours ... there does not seem to be a single "language of colour".

3 By die drie metafunksies wat gelyktydig betrokke is in elke handeling van sosiale kommunikasie (te wete, die begripvormende, die interpersoonlike en die tekstuele) kan kleur betrek word om in al hierdie funksies te voldoen (Van Leeuwen 2011:10-12, met verwysing na Halliday).

4 Daar is tans oor die sewe duisend tale ter wêreld (Beeld. 2017. 28 Oktober: 17), wat verteenwoordigend is van verskillende 'taalfamilies', onder andere dié van IndoEuropese taalgroepe, soos Engels, Hindi en Antieke Grieks, en die non-Indo-Europese tale wat ook Hopi, Chinees, isiXhosa, isiSotho en Swahili insluit. Sprekers van elke afsonderlike taal handhaaf verskillende beskouinge wat as die 'Whorf-hipotese' of die 'Whorf-Sapir-hipotese' bekend staan. Die benaming 'linguistieke relatiwiteit' word meer dikwels in hierdie verband gebruik, wat beteken dat kultuurverskille in verskillende tale gereflekteer en daardeur aangevul word (Van Leeuwen 2011:45).

5 Daar moet onderskei word tussen die vier psigologiese primêre kleure - blou, groen, geel en rooi - en die drie primêre kleure (suiwer rooi, suiwer blou en suiwer geel [met die uitsluiting van swart, wit en grys]) wat in die fisiese aanwending van kleur gemeng kan word om enige ander kleur te skep (Osborne 1968:270-71). 
objektief beoordeel word, wat impliseer dat persoonlike beskouinge en vooropgestelde menings oor kleurterme se 'korrekte' klassifikasie en wyse van aanwending ter syde gestel word. Om dit te bewerkstellig, is daar reeds in die 1900 's gepoog om kleurbeskrywing op 'n rasionele wyse vas te pen. Die vroegste formele klassifikasie is waarskynlik dié van die Amerikaanse kunstenaar, Munsell (1858-1918), wat 'n sisteem daargestel het waarvolgens enige kleur met groot presisie omskryf is. Dit het drie attribute ingesluit: kleurskakering ('hue'), kleurkwaliteit ('value') en kleurgehalte ('chroma') (Osborne 1968:270-71). ${ }^{6}$ Alhoewel Munsell se drie maatstawwe geredelik aanvaar en gebruik is, verfyn Biggam (2012:3-5) die sisteem met 'n toegevoegde vierde attribuut, naamlik tint ('tone'):

- Kleurskakering ('hue') hou verband met waarneembare lig wat deur golflengte bepaal en deur die mens waargeneem word. Dit hou dus verband met 'n bepaalde posisie op die kleurspektrum. Oor die algemeen dui skakering op 'n 'suiwer' kleur (dit is kleur sonder enige bygevoegde wit, swart of grys) soos rooi, groen of blou.?

- $\quad$ Kleurkwaliteit (ook -suiwerheid of -versadiging) ('value' of 'saturation') dui op ligte of donker kleurskakerings, wat verkry word deur die byvoeging van 'n hoeveelheid grys by 'n kleur. In Afrikaans word die woord 'helder-' in samestelling met die kleurbenaming gebruik. Dit moet egter nie met die attribuut helderheid (of glans) (infra) verwar word nie. Aan die hand hiervan dui die term 'helderrooi' eerder op kleurkwaliteit of suiwerheid (met geen of 'n geringe mate van bygevoegde grys) as op kleurskakering, terwyl 'dofrooi' op 'n sekere hoeveelheid bygevoegde grys dui.

- Kleurgehalte of helderheid ('brightness') dui op die intensiteit van die kleur, wat deur die hoeveelheid lig wat deur die oog waargeneem word, bepaal word. Gevolglik kan die aard en oorsprong van die intensiteit verskil. So byvoorbeeld kan 'n voorwerp met 'n dowwe voorkoms glansend

${ }^{6}$ Irwin 1974:10-12 bied 'n gedetailleerde uiteensetting van die bekende 'Munsellkleurboom'.

7 Kleur, of die ekwivalent daarvan, word in sommige moderne taalgemeenskappe slegs met die enkele eienskap, kleurskakering, vereenselwig. Die woord 'kleur' kom egter nie in alle samelewings voor nie. In sulke gevalle word die algemene voorkoms van 'n objek nie met kleur nie, maar eerder met 'n verskeidenheid van visuele kenmerke soos glans, 'n growwe of gladde tekstuur, selfs vogtigheid of dorheid uitgebeeld (Wierzbicka 2006:1-4).

8 By gebrek aan 'n meer gepaste woord in Afrikaans kan 'versadiging' ook van 'saturation' gebruik word. 
voorkom, indien dit helder verlig sou wees. Dit kan ook 'n blink oppervlakte hê, of self die bron van lig wees, soos 'n kers of 'n lamp. In sommige gemeenskappe word daar groter klem op helderheid as op kleurskakering geplaas, sodat daar min basiese kleurterme in hul woordeskat voorkom. Hierdie taalgebruikers interpreteer kleur dus in terme van 'lig' versus 'donker'.'

- Die 'addisionele' attribuut tint ('tone') dui op die hoeveelheid wit of swart wat by 'n kleur gevoeg word om kleurwaardes te skep wat tussen lig en donker varieer. ${ }^{10}$ So byvoorbeeld kan blou-skakerings wissel tussen ligblou ('pale blue', met groot hoeveelhede wit bygevoeg) tot donkerblou ('dark blue', met toegevoegde 'swart'). Soos die Engelse 'pale' en 'dark', gebruik ons ook in Afrikaans die woorde 'lig-' en 'donker-' om tinte as samestellings in kleurbenamings te omskryf.

Ten spyte van hierdie onderskeidende kenmerke, maan Biggam (2012:2-3) dat daar tot nog toe geen gestandaardiseerde terminologie vir die beskrywing van kleur saamgestel is nie, wat steeds tot die algemene verwarring bydra. ${ }^{11}$ Hierdie beskouing word ook deur Van Leeuwen (2011:15) onderskryf: ' ... there does not seem to be a single "language of colour" ... [T] here is a multitude of codes, conventional associations and uses of colour, many of them with limited contexts of application and limited semantic domains'.

Die aard van die kleure wat ons raaksien, is die eindresultaat van die gekompliseerde wisselwerking tussen die wetenskaplike eienskappe van lig, ${ }^{12}$

9 Ratliff 1976:320-21 beskou helderheid as die mees fundamentele aspek van kleur, aangesien dit met beide achromatiese en chromatiese visie verbind is. Dit is ook die enigste faktor wat eie is aan beide normale en abnormale visie (byvoorbeeld, kleurblindheid), en daarom waarlik universeel.

10 Van Leeuwen 2011:109 huldig die mening dat die woord tint uitsluitlik op ligte skakering betrekking het, en geensins van 'donker' kleure gebruik kan word nie.

11 Die begrippe 'chroma', 'intensiteit', 'konsentrasie' en 'versadiging' kom soms almal as aspekte van die eienskap suiwerheid ('saturation') voor. Die verwarring word vererger deurdat outeurs dikwels dieselfde begrippe vir verskillende eienskappe gebruik. Osborne 1968:271 verwys na die heersende probleem, maar beland tog in dieselfde strik met sy definiëring van helderheid en suiwerheid.

12 Eie aan lig is die twee faktore intensiteit, wat op die hoeveelheid lig dui, en golflengte wat betrekking het op lig se kleur. In die navorsing wat op visie fokus, is veral die fotiese element ('ligsterkte' of 'luminosity') belangrik. Liggolflengte word deur straalbreking blootgelê: Die mens neem slegs die golflengtes tussen vier-en sewehonderd nanometers waar, duidelik sigbaar in 'n reënboog. Die gedeelte van die spektrum onder vierhonderd nanometers bestaan uit ultraviolet wat onsigbaar is vir die mens (maar nie vir bye nie), en bo sewehonderd nanometers kom die onsigbare infrarooi voor (Ratliff 1976:312-13). 
die struktuur van die menslike oog, omgewingsfaktore ten tyde van die waarneming van die voorwerp, die fisiese eienskappe van die objek en die wyse waarop die brein al hierdie inligting ontvang en interpreteer. Volgens Biggam (2012:2) is die proses van kleurpersepsie en die verwerking en aanpassing van hierdie inligting in taal bespeurbaar. Die ervaring van kleur kan, benewens 'n sintuiglike ervaring, ook aan die emosionele gekoppel word. ${ }^{13}$ Dit sou beteken dat kleurwoorde nie slegs chromaties aangewend word nie, maar genuanseerd die teks kan verryk om ook emotief tot die leser te spreek. Sintuiglike gewaarwordinge soos gehoor, gevoel, reuk en smaak, maar veral sig, wat die skerpste van die sintuie is, dra daartoe by dat die leser 'n uitbeelding in die geestesoog duideliker kan visualiseer. ${ }^{14}$ Gevolglik kan kleurwoorde ook reaksies ontlok soos woede, vreugde, afguns en hartseer, wat tot die wisseling van stemming kan bydra. Kleure kan ook hoogs suggestief wees, aangesien die meeste kleurwoorde ontwikkel het uit kontekstuele terme wat achromatiese inligting bevat het. Dit lei tot betekenisvolle konnotasies met abstrakte begrippe soos koue, hitte, sterkte, swakheid, siekte, gesondheid, selfs manlik en vroulik (Clarke 2003:2, met verwysing na Sivik [1997:187]). Aangesien hierdie sintuiglike of emosionele ervaring van kleur 'n objektiewe beoordeling kan bemoeilik, was D'Hérouville (1930:56) van mening dat daar nie te veel oor kleure gedebatteer moet word nie. Meer as 'n halfeeu later word hierdie beskouing steeds gehandhaaf as Eco (1996:148) James Gibson aanhaal: '.. the meaning of the term colour is one of the worst muddles in the history of science'. ${ }^{15}$

Bykomend tot die verwarring oor die betekenismoontlikhede van antieke kleurterminologie, kan 'n verdere knelpunt - nou egter op die mees basiese vlak - uitgelig word: Indien die moderne leser nie daarop ingestel is nie, kan dit gebeur dat 'n kleurwoord onbewustelik net nie 'raakgelees' word nie. Waar 'n sekere skerpsinnigheid deur die noukeurige lees van tekste nie ontwikkel is nie, mis die leser dus die impak van die term. Voeg hierby ook bykomende nuanses en die waarskynlike doelwitte van enige uitnemende woordkunstenaar, daar dit stilisties binne die digter se vermoë is om 'n visuele effek te beklemtoon, bloot deur die noukeurige plasing van ('n) spesifieke kleurwoord(e) in 'n versreël. Kleurterme

13 Die sintuiglike gewaarwordinge van smaak en reuk is onlosmaaklik verbind. Smaak word verbind met die sensasie van soet, suur, sout en bitter wat deur reuk verfyn word. 'n Bykomende aspek van sinestesie is die vermoë om kleur deur die tassin waar te neem. Sien Lilja 1972 se gedetailleerde uiteensetting van geur as stilistiese tegniek in die Griekse en Romeinse digkuns.

14 Volgens Descartes (1596-1650), vader van die moderne filosofie, word kleure onder andere helder en duidelik ervaar, wanneer hulle bloot as sensasies of gedagtes beskou word (Kenny 1999:126).

15 Gibson 1968. 
kan ook temas uitbou, onderafdelings met mekaar verbind en 'n spanningslyn opbou.

Hedendaags word die standpunt gehuldig dat alle menslike wesens kleur op dieselfde fisiese wyse en met dieselfde visuele meganismes waarneem (Ratliff 1976:320; Pentak \& Roth 2004:6). Daar kan dus aanvaar word dat dit ook van toepassing is op die proses van kleurpersepsie in die Oudheid. Daar is inderdaad talle treffende en dramatiese voorbeelde van kleurgebruik in Griekse en Romeinse poësie, wat daarop dui dat antieke digters wel die stilistiese aanwending van kleurwoorde hoog geag het. Uitbeeldings van 'n antieke wêreld het in sekere gevalle van hedendaagse weergawes verskil. Moderne wetenskaplike bevindinge wat lukraak op antieke terminologie toegepas is, het tot misverstand en waninterpretasie aanleiding gegee. Ook het die nodige sensitiwiteit ontbreek om oplossings te bied vir die implikasies van hierdie kleurterme (Irwin 1974:22). Vir die moderne navorser lê die knoop dus in die ontrafeling van die antieke skrywer se interpretasie van 'n kleurbeeld en die rede(s) vir sy keuse van ('n) spesifieke kleurwoord(e) vir die uitbeelding daarvan.

\section{Kleurbeskrywing in die Griekse Oudheid}

Vir ons kom die Homeriese wêreld besonder kleurloos voor, aangesien die digter 'n voorliefde toon vir die kleure wit en swart. Daarbenewens wend Homeros kleure op 'n 'ongewone' wyse aan: Die aarde is 'swart' ( $\mu \varepsilon ́ \lambda \alpha \varsigma, I l . B[2] .699)$ en gedurende

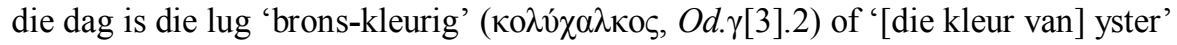
( $\sigma \iota \delta \eta ́ \rho \varepsilon о \varsigma, ~ O d$. o[15].328). Die see word nie net as 'swart' ( $\mu \varepsilon ́ \lambda \alpha \varsigma, ~ I l . ~ \Omega[24] .79$

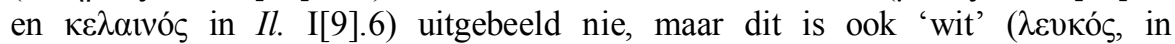

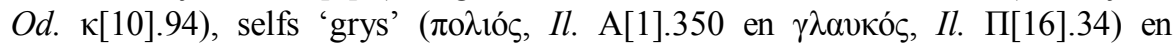

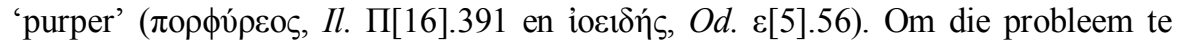
vererger, kan 'n term soos àpyós, wat met die betekenismoontlikheid 'wit' van 'n gans (Od. o[15].161) voorkom, ook die 'glans' van 'n wildevark se slagtande (Il. K[10].263-64), die 'blinkvet' voorkoms van offerdiere (Il. $\Psi[23] .30)$ en die 'ratsheid' van honde (Il. A[1].50, $\Sigma[18] .283$ en Od. $\pi[17] .62)$ aandui.

Dit is ook opvallend hoe Griekse digters oor eeue aanpassings gemaak het om uitdrukking aan hul belewenis van kleur te gee. As sprekende voorbeeld kan hul beskrywings van die kleure van die reënboog voorgehou word. Ons vind dit

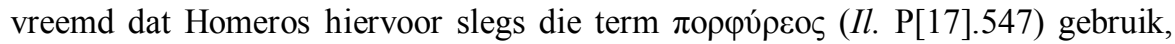
wat ons - met 'n moderne beskouing - slegs met purper vereenselwig. Heelwat later interpreteer Xenophanes (sesde eeu vC) 32.1-3 (fr. 28D) 'n reënboog as 'n

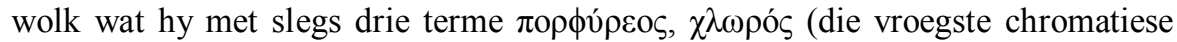

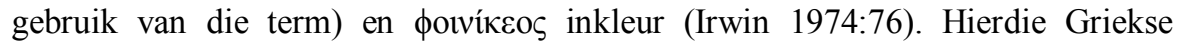
kleurterme word hedendaags onderskeidelik met blou, indigo of violet, geel-groen 
(wat in die middel van die spektrum voorkom) en oranje-rooi vereenselwig. Amper twee eeue later beskryf Aristoteles (vierde eeu vC) in sy Meteorologica 372a die

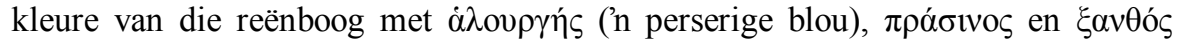

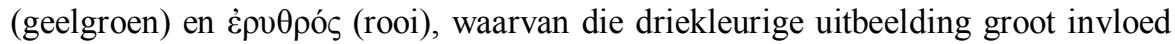
op latere filosowe uitgeoefen het. Alhoewel hy nie 'n rasionele verklaring bied vir sy keuse van die kleure nie, skryf hy sy vermoë om reënboogkleure te onderskei aan persoonlike interpretasie toe (André 1949:13). Ook Poseidonius (tweede/eerste

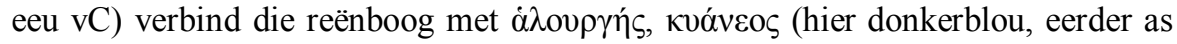

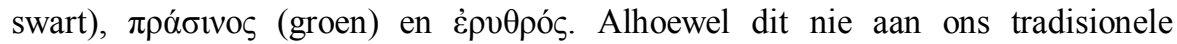
beskrywing van 'n reënboog voldoen nie, word dit duidelik in watter mate daar in die Oudheid gepoog is om aan visuele waarneming uiting te gee, en dit met die beskikbare kleurterminologie. ${ }^{16}$

Lig speel 'n besondere rol in die aard van kleur, daar dit op 'n bepaalde wyse teruggekaats word. Ook is die visuele of fisiese aard van kleur belangrik, net soos die verband met die oppervlakte of 'uiterlike vorm' van die voorwerp waarop kleur voorkom. Sommige van hierdie eienskappe van kleur is reeds in die vyfde eeu vC deur Plato, Meno 75b geëien, wat die vroegste beskrywing van die aard van kleur

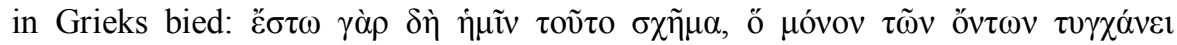

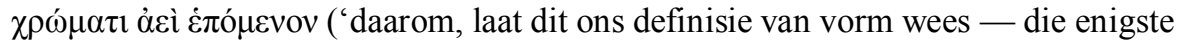
ding wat altyd met kleur saamgaan') (Irwin 1974:27).

Ten spyte van die talryke voorbeelde van 'ongewone' kleurgebruik, is daar tog ook dié wat aanvaarbaar en, volgens ons standaarde dalk 'korrek', voorkom ${ }^{17}$

16 Verskeie kleurwoorde is oor tyd in Grieks geskep om 'ontbrekende' kleurskakerings

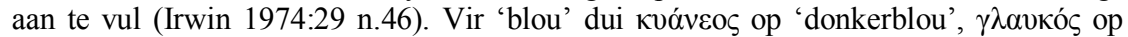
'ligte blou'en iøátıs op 'n donkerblou kleurstof ('wede', Engels 'woad'). Verskeie

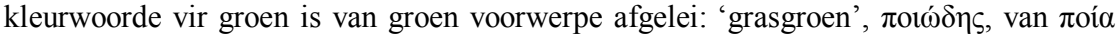
('gras'); 'padda-groen', $\beta \alpha \tau \rho \alpha ́ \chi \varepsilon 10 \varsigma, \quad$ van $\beta \alpha \tau \rho \alpha ́ \chi \alpha \varsigma$ ('padda'); 'smaraggroen',

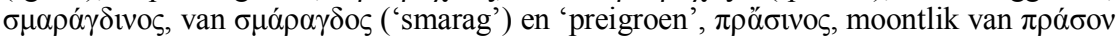
('prei'), alhoewel Wallace 1927:16 eerder $\pi \rho \alpha \sigma i \alpha ́$ ('tuin') voorhou. Bradley 2006:2, met verwysing na Blanc, bespreek die invloed van voorvoegsels vir kleurbeskrywing in antieke Grieks. Anders as in Frans wat agtervoegsels aanlas (blanchâtre, noiraud, rouget, brunot en jaunelet), kom prefikse veral in Hippokratiese en tegniese Griekse tekste voor: $\delta 1 \alpha-, \dot{\varepsilon} v-, \dot{\varepsilon} \xi-, \dot{\varepsilon} \pi l-, \pi \alpha \rho \alpha-$ en $v ं \pi 0-$, met $\dot{\varepsilon} v-$ wat besit aandui (byvoorbeeld $\dot{\varepsilon} v \omega \chi \rho o \zeta$, van die geel substansie in die lewer). Ook dui غ̇ंt- op oppervlakte-kleur en kleurskakering; $\delta 1 \alpha-$ word gebruik van die opvallende teenwoordigheid van kleur, met $\grave{\varepsilon} \xi$ - (die mees gekompliseerde van die prefikse) wat op 'n intensiewe kleur dui, gewoonlik aan die buitekant van 'n voorwerp en dikwels as aanduiding van 'n afwyking van die normale.

17 Voorste Griekse filosowe het vurig debat gevoer oor die verband tussen visie (as die primêre sintuig) en die verkryging en verwerking van kennis. Bradley 2011:57-68 bied 'n gedetailleerde uiteensetting van beskouinge oor kleur deur die Pre-Sokrate (Alkmaion en Empedokles), die atomiste (Leukippos en Demokritos), Plato (in sy Meno), 
en wat op die effektiewe gebruik van kleurterme kan dui. ${ }^{18}$ Dit word dus duidelik dat die fokus in 'n groot mate op die 'onaanvaarbare' of selfs die 'onakkurate' geplaas is.

\section{Navorsing oor die gebruik van kleur in die Griekse letterkunde}

Die belangstelling van kritici in die vroeë twintigste eeu was merendeels op die chromatiese gebruik van kleurterme in die antieke Griekse letterkunde toegespits. Navorsing was ook meer gefokus op die beskrywing van die kleurterme en kwantifisering van hul gebruik as op hul stilistiese aanwending. 'n Waardering van en begrip vir Griekse (en in 'n sekere mate vir die Romeinse) kleurterminologie is ook vir 'n lang tyd deur verskeie teorieë oor Griekse kleurwaarneming en -terminologie gekortwiek. So bied Platnauer (1921:153-62) 'n oorsig van die fynere nuanses van die verskillende kleurkategorieë in die werke van al die Griekse outeurs van Homeros tot by Xenophon. Hy beskou die verskil tussen kleure kwantitatief eerder as kwalitatief. Wit en swart word as volwaardige kleure beskou, glans is belangrik, maar nie die kleur of tint nie. Alhoewel hy die probleme wat met kleurontleding gepaard gaan, toelig, bied hy geen oplossings nie, maar wys tog op 'n belangrike punt: 'Kleur' het nie vir die Grieke van ouds dieselfde betekenis as vir die moderne mens nie (Irwin 1974:14). Wallace (1927) fokus veral op Homeros se vreemde gebruik van kleurwoorde, wat sy helaas as nutteloos afmaak. Kober (1932) bestudeer kleurterme in die Griekse digkuns van Homeros tot die Aleksandrynse era, maar met uitsluiting van die epigrammatici. Haar studie bied 'n handige oorsig van die voorwerpe wat met spesifieke kleurterme vereenselwig word. Sy laat egter na om die ontwikkeling van kleurwoorde en die insiggewende semantiese aanpassings wat geleidelik plaasgevind het, toe te lig. Osborne (1968) fokus op die linguistiese gewoontes van die antieke Grieke aan die hand van hul gebruik van kleur. Hy kom tot die gevolgtrekking dat die Griekse kleurwoordeskat skraal was en dat tinte nie noukeurig onderskei is nie, maar wel kleure se helderheid en intensiteit. ${ }^{19}$ Irwin (1974) beperk haar uiters deeglike studie tot 'n in-diepte analise van die terme $\chi \lambda \omega \rho o ́ \varsigma($ 'groen-geel', 'geel', 'liggroen', 'bleek', die

Aristoteles oor kleurpersepsie (in Meteorologica, De Anima en De Sensu et Sensibilibus), Theophrastus (in sy De Sensibus) en die twee filosofiese tradisies van die Hellenisme, Stoïsisme en Epikurisme. Vir 'n volledige oorsig van Aristoteles en die De Coloribus, sien Gottschalk 1964:59-85.

18 Sien onder andere Euripides, Hel. 179-82, Pindaros, O. 6.39-45 en 55 en Sophokles, OC 668-719; Irwin (1974:4 n.4 met verwysing na Bowra) wys op Simonides se lewensgetroue gebruik van kleur, ook as die eerste om Koóveos van die see te gebruik (alhoewel dit onseker is of die kleur 'blou' daarmee verband hou).

19 Dit word aanvaar dat Osborne hier met die woord 'intensiteit' na die attribuut suiwerheid verwys. 
achromatiese betekenis 'vars' en ook die metaforiese betekenismoontlikheid

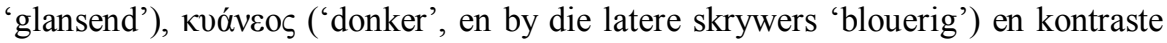
van lig en donker. Sy onderskryf ook die nou reeds-gevestigde beskouing dat Griekse terme dikwels eerder op glans, tekstuur en kontras as op kleurnuanses dui. Die omvangryke bydrae van Maxwell-Stuart (1981a \& 1981b) fokus op die Griekse terme $\gamma \lambda \alpha v \kappa o ́ \varsigma$ ('glansend' in Homeros; by latere skrywers 'blougroen' of 'grys') en $\chi \alpha \rho \operatorname{có}_{\varsigma}$ (behalwe 'hewig' of 'fel', ook 'glansend' en 'blougrys', veral van die kleur van oë en die see). Hy ondersoek die gebruik van kleur in beide prosa en poësie, maar in 'n poging om slegs die 'normale' betekenis van die term vas te pen, gee hy voorkeur aan prosa. Hy neem ook nie die effek van tekstuur, lig of glans in ag nie. Waar sommige van die aannames tekstueel onaanvaarbaar is, beoordeel hy die betekenismoontlikhede bloot as metafore. ${ }^{20}$ So 'n benadering is bejammerenswaardig, aangesien dit die leser nie toerus om die fynere nuanses van kleurterme raak te lees nie. Clarke (2004) se bestudering van Griekse kleurterminolgie word volgens Bradley (2011:16-17) as die mees logiese en sensitiefste ondersoek na die komplekse kleurkategorieë van die Oudheid beskou. Clarke bevind dat daar 'n linguistiese 'prototipe' as middelpunt in kleurwoorde voorkom met verskillende kleure wat, volgens die ou Grieke se belewenis daarvan, in konsentriese sirkels daarom beweeg. Hierdie antieke 'prototipes' sou as kontakpunte dien vir kognitiewe vlakke wat kleur, lig, beweging en gemoedstoestand ingesluit het.

Reaksie op die ongewone beskrywings in die Griekse letterkunde is op uiteenlopende wyses gehanteer: Sommige kritici het 'afwykings' bloot geïgnoreer of met lojale verdraagsaamheid aanvaar, terwyl ander weer hierdie beskrywings as 'poëties' (met ander woorde 'letterkundig onjuis') afgemaak het. Die oorgrote meerderheid het egter een van twee beskouinge voorgestaan: Party het die sogenaamde 'retinale afwyking' van die antieke Grieke voorgehou, terwyl ander 'n oplossing gesoek het in die 'onvolledigheid' (of selfs die 'gebrekkigheid') van die Griekse kleurterminologie. Hierdie beskouinge is vir die eerste keer deur Goethe in sy Zur Farbenlehre ${ }^{21}$ (1810) geopper. Bykans een honderd jaar voor Goethe het die Engelse fisikus en wiskundige, Sir Isaac Newton, bevind dat sonlig met behulp van 'n glasprisma in die kleure van die spektrum opgebreek kan word. ${ }^{22}$ In sy Opticks

20 Clarke 2004:134 wys op die misbruik van die woord 'metafoor', wat in die analise van kleurkategorieë al te dikwels buite hul kognitiewe verwysingspunte aangewend word.

21 Zur Farbenlehre in Sämtliche Werke. München. Sien volume 22:7-42 en veral 39-42.

22 Die kleurspektrum behels sewe kleure wat altyd in dieselfde volgorde voorkom en waarvan die wydte van die kleurstroke van kleur na kleur verskil. Newton het 'n verband probeer skep tussen die kleure van die spektrum en die sewe note van die diatoniese musikale skaal. Soms word daar slegs na ses kleure verwys, met indigo uitgelaat (Irwin 1974:10 n.18). 
(1704) toon hy verder dat hierdie verskillende kleure met 'n tweede lens gekombineer kan word om weer wit lig te vorm. Goethe het hierdie bevindings van Newton in Zur Farbenlehre probeer weerlê in 'n poging om sy eie teorieë te bewys. Dit is opvallend dat hierdie publikasie van Goethe kort na die publikasie van John Dalton (1766-1844), 'n Engelse chemikus, se bevindings gevolg het (Irwin 1974:5-6). In sy voordrag getitel Extraordinary facts relating to the vision of colours with observations (1798) het Dalton die eienskappe van Daltonisme uiteengesit. Hy het nooit die toestand as kleurblindheid beskryf nie, maar dit implisiet met 'n retinale onvermoë vereenselwig. ${ }^{23}$ Gevolglik is baie van die vreemde kleurbeskrywings van die antieke Grieke aan hierdie afwyking toegeskryf, wat ook aanleiding gegee het tot WE Gladstone, die Britse politikus, se bevindings in die middel van die negentiende eeu: '.. the organ of colour and its impressions were but partially developed among the Greeks of the heroic age' ${ }^{24}$ Dit is ook insiggewend dat Charles Darwin se werk On the origin of species (1859) ná Gladstone se eerste publikasie in 1858 verskyn het, maar voor die vloedgolf van bydraes wat as reaksie in die 1870's die lig gesien het. Voor Darwin is daar reeds na die evolusie-teorie verwys, maar sy benaming 'natuurlike seleksie' was uniek en het groot belangstelling opgelewer.

Ook Alfred Geiger (Frankfurt, 1876) het hom op kleurwaarneming in die Oudheid toegespits. ${ }^{25}$ Hy het vreemd genoeg bevind dat die kleure blou en groen in die vroegste Griekse letterkunde ontbreek, wat sou beteken dat die Grieke slegs 'swart, 'rooi' en 'goud' (of 'geel') kon waarneem. Hugo Magnus (1877), medikus en klassikus, het op Geiger se teorieë uitgebrei en het tot die slotsom gekom dat die mens in die vroegste tye slegs lig kon waarneem, maar geen kleur nie. Skynbaar sou die ontwikkeling van perseptuele vermoëns algaande plaasgevind het met 'lig-ryk' kleure (dié tussen wit en rooi) eerste, waarop rooi en geel gevolg het, dan groen met blou en violet heel laaste, wat die minste lig sou vertoon.

Nietemin het die sistematiese analise van Griekse kleurpersepsie gedurende die volgende eeu bewys dat die Grieke inderdaad oor 'n hoogs gesofistikeerde, alhoewel baie subtiele, kleursisteem beskik het. Die eerste teenkanting teen die teorieë van Gladstone et al. was dié van Anton Marty. ${ }^{26}$ Sy bevindings dui daarop

23 Die geschichtliche Entwickelung des Farbensinnes, Leipzig (1877).

24 Sien Gladstone 1858:456-99 en 1877:366-88 (Irwin 1974:6 n.7).

25 Zur Entwickelungsgeschichte der Menschheit (eerste uitgawe 1871, tweede 1878, Stuttgart), veral 1878:5-60.Vir sy bespreking van die kleur 'blou', sien 1878:49 en 52; en vir die vroegste waarneming van kleure, sien 54 en 57.

26 In sy Die Frage nach der geschichtichen Entwickelung des Farbensinnes (Wenen, 1879) het Marty sy navorsing op onbeskaafde stamme se gebruik van helder kleure gefundeer, wat in die oorblyfsels van hul versierings aangetref is. Wat die antieke letterkunde betref, het hy die 'vreemde' gebruik van kleure aan poëtiese vryheid toegeskryf, met die 
dat die vroeë Grieke geen behoefte aan 'n uitgebreide kleurterminolgie gehad het nie en dat dit ook nie vir hulle nodig was om kleur telkens te beskryf nie. ${ }^{27}$ Hy het egter nagelaat om kleurterme in hul literêre konteks te ontleed, en het sy bevindings op afleidings en waarskynlikhede gebaseer. In dieselfde jaar het die sielkundige, Grant Allen (The colour sense: Its origin and development, Boston, 1879), bevind dat die teoretiese evolusionêre tydskaal van beide Geiger en Magnus te vinnig verloop het om met argeologiese en antropologiese bevindings te strook.

Ook in reaksie, en veral in kontras met Schultz ${ }^{28}$ se bevindings vroeg in die twintigste eeu, het die navorsing van onder andere Wallace (1927), Kober (1932), Young (1964), Osborne (1968) en Irwin (1974) gevolg. Hulle het onteenseglik bewys dat die visie van die Grieke normaal was, wat daarop sou neerkom dat slegs die Grieke se kleurterminologie ontoereikend was. Platnauer (1921) se beskouing dat 'kleur' nie vir die Oudheid dieselfde betekenis gehad het as vir ons nie, is hier besonder relevant. Alhoewel Deacy \& Villing (2004:88) se sensitiewe studie van

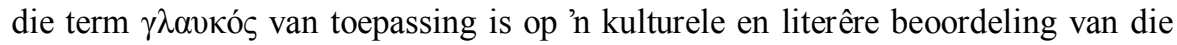
godin Athena, kan hul beskouing ook op die kleursisteme van die Oudheid toegepas word: 'Like all colour terms and representations, [a term] should not be reduced to strict chromatic meaning, but regarded in the context of discourse between artists and their audience, as a symbol and a signifier'.

\section{Kleur in die Romeinse samelewing}

In die alledaagse lewe van die Romeine het kleur 'n baie besondere, maar ook belangrike, rol gespeel. Alhoewel hul argitektuur en beeldhouwerk vir lank met die glansende wit van marmer geassosieer is ${ }^{29}$ dui die jongste navorsing daarop dat die

klem op glans eerder as kleurskakering (Irwin 1974:7-8, met verwysing na Die Frage. Sien veral 95-105 vir die ontwikkeling van 'n tegniese woordeskat).

27 Dit is insiggewend dat Biggam 2012:194 meer as 'n eeu later dieselfde beskouing handhaaf: '... not all societies are equally interested in colour, and the researcher may find that the literature which he / she is studying rarely uses colour terms'.

28 In sy Das Farbenempfindungssystem der Hellenen (Leipzig, 1904) het Schultz normale en abnormale kleurpersepsie bestudeer. Hy het veral gefokus op antieke uitbeeldings van die reënboog, die kleurteorieë van Demokritos en Plato, asook Pheidias se uitbeelding van Zeus se tempel by Olimpië. Hy het bevind dat die Grieke almal blou-geel kleurblind was. 'n Soortgelyke studie oor die Romeine se kleurpersepsie is deur KE Goetz (Waren die Römer blaublind?) gepubliseer in Archiv für lateinische Lexikographie und Gramatik 14 (1905), 75-88; 15 (1908), 527-47 (Irwin 1974:9 n.17).

29 Hierdie beskouing is veral deur Johann Joachim Wincklemann (1717-68), die Duitse kunsgeskiedkundige en argeoloog, gepropageer. Hy was agent van kardinaal Albani, voorste versamelaar van antikwiteite in Renaissance Rome en die outeur van Geshichte der Kunst des Alterthums (1764). Hy is ook as die 'vader' van kunsgeskiedenis beskou (Beard \& Henderson 2001:8, 68-74). Selfs Zanker 1988:105 handhaaf hierdie einste 
Romeine ook in hierdie kunsvorme hulle voorliefde vir kleur uitgeleef het. Hul tempels ${ }^{30}$ en beeldhouwerk ${ }^{31}$ was inderdaad met kleur versier, '... to surprise or shock the public ...', volgens Bradley (2011:427).

siening, en dit meer as twee eeue later: " Nothing is too good for the gods" was now the slogan. The gleaming white temple facades, built of marble ... with their dazzling ornament, sometimes of real gold, became hall marks of the new age' [my beklemtoning].

30 Beard \& Henderson 2001:84, 166 verwys geensins na die gebruik van pigmente op beeldhouwerk of op die marmer van tempels nie, en dit terwyl eksotiese gekleurde steen in die Forum Augustum aangetref is: Frigiese purper (pavonazetto), africano met 'n rooiswart kleur, Tunisiese geel (giallo antico) en 'n groen cipollino, afkomstig van Euboea, Griekeland. Etlike jare later wys Østergaard 2008:40, 43, 62 op die gebrekkige en sporadiese navorsing in hierdie verband, 'n beskouing wat Zink \& Piening 2009:109 n.1, 111-14 egter met hul navorsing weerlê. Hulle publiseer 'n sinopsis van Romeinse monumente (die Forum Augustum, Ara Pacis, die tempels van Mars Ultor en Fortunus, en die Colosseum), waarvan die marmer deur Piening aan pigment-analise onderwerp is. Met die rekonstruksie van die tempel van Apollo Palatinus (Zink 2008:47-63) is die beskikbare fragmente aan ultraviolet-spektrometrie onderwerp om die ingewikkelde kleurskema te rekonstrueer. Groot gedeeltes van die tempel is wel in wit marmer gelaat, onder andere die trap, die mure van die cella, die suile en moontlik ook die podium. Verskeie kleure kom egter op die eksterieur van die tempel voor, telkens op strategiese plekke soos die kapitele, entablemente en deurkosyne, beklemtoon met ligte kleure soos geel, oker en goud, ook donker kleure waaronder blou, donkerbruin en donkerrooi, en in 'n mindere mate helderrooi en groen. Hierdie kleure word inderdaad in letterkundige beskrywings van die tempel vermeld wat nou vir die eerste keer met die argeologiese bevindings versoen kan word. Ter stawing word Propertius 2.31 se gedetailleerde, maar redelik komplekse en problematiese beskrywing van hierdie tempel, voorgehou.

31 Alhoewel kleur op Grieks-Romeinse beeldhouwerk tans meestal met die blote oog onwaarneembaar is, het pigment-identifikasie onomstootlik bewys dat kleur wél daarop aangebring was. Veral drapeersels, oë, wimpers, lippe, hare en bykomstighede is met kleur beklemtoon. Marmer, terracotta, vulkaniese klip, kalk- en sandsteen is dikwels met pleister(kalk) bedek wat geheel en al met kleur bedek was. Die eerste van twee kleur-rekonstruksies - die Prima Porta Augustus (waarvan sommige pigmente nog herkenbaar was) en die borsbeeld van Caligula - het merkwaardige resultate opgelewer. In 2008 is beide in die J Paul Getty Museum se uitstalling 'The color of life: Polychromy in sculpture from antiquity to present' opgeneem. Hierby ingeslote was ook al die rekonstruksies wat vanaf 2003 in uitstallings ('Bunte Götter / Gods in color') in Europa en Amerika te siene was. Sien ook Mary Beard se webjoernaal ('A Don's life') (Desember 17, 2007) vir 'n insiggewende aanlyn-gesprek met Østergaard, kurator van die Ny Carlsberg Glyptotek, Kopenhagen. Hy benadruk die feit dat die antieke wêreld se belewenis van skoonheid van die moderne beskouing verskil: '... research on ancient sculptural polychromy is not an exercise designed to confirm or conform to modern aesthetics of sculpture. It is an historical enquiry'. So ook Bradley 2011:427-50, volgens wie die volle impak en betekenis van kleurpigmente op antieke beeldhouwerk nog geensins voldoende nagevors is nie. 
In hul wonings het die Romeinse elite hulle met kleur omring, en veral uitsonderlik was die manjifieke muurskilderinge ${ }^{32}$ en die mosaïeke ${ }^{33}$ wat as vloerbedekking aangebring is. Die mure in hierdie rykmanshuise is van die vloer tot by die plafon met helder kleure versier: swart, wit, blou, geel en veral die 'Pompejaanse rooi'. Dit is aangevul met delikate versierings, trompe-l'oeil pilare, uitbeeldings van weelderige vrugte en blomme, vistas met uitsonderlike argitektuur, voëls op geverfde gordyne en 'vensters' wat wonderlikbaarlik op eksotiese tuintonele oopmaak (onder andere die 'Tuinkamer' te Prima Porta, eens die weelderige plattelandse woning van Augustus). Hierby kom ook afsonderlike panele (pinakes), wat die versiering van 'n vertrek ryklik sou aanvul. ${ }^{34}$

Sonder die voordele van moderne glas wat lig ruimskoots deurlaat, sou mens kon aflei dat sommige van die binne-vertrekke besonder donker was. ${ }^{35}$ Hierdie aspek is vir seker in ag geneem by die versiering daarvan, wat sou beteken dat die kunstenaars die interaksie tussen kleur, lig en donkerte in ag geneem het, ' $\mathrm{n}$

32 Die uitbarsting van Vesuvius in $79 \mathrm{nC}$ het met geweldige verwoesting en lewensverlies gepaard gegaan. Ironies genoeg was die ontdekking van die antieke Kampaanse stede Pompeii, Herculaneum en Stabiae, wat onder die vulkaniese as begrawe was, 'n argeologiese triomf. Uitgrawings wat reeds in 1748 begin het, gaan nou vir bykans drie eeue onverpoos voort en vir die eerste keer kan die antieke wêreld in sy volle glorie en kleur - beleef word. Chemiese analises op Pompejaanse muurskildering toon dat hierdie kunswerke in tempera aangebring is, wat baie tot die bewaring daarvan bygedra het (Beard \& Henderson 2001:23-63).

33 Afkomstig uit die Huis van die Faunus is die beroemde Alexander-mosaïek en agt ander kunswerke, wat Nyltonele, die glurende leeu, Kupido op 'n tier, 'n kat en voëls, 'n nimf en sater, maskers met blomme en vrugte, duiwe en seekos insluit. Almal is as manjifieke vloerbedekkings gebruik (Beard \& Henderson 2001:14-19).

34 Pompejaanse muurskildering is deur die Duitse navorser, August Mau (1840-1909) in vier style verdeel om klassifikasie en stilistiese analise te orden: die Eerste styl van die tweede eeu vC, die Tweede of Argitektoniese styl ( $c a$. 100-15 vC), die Derde styl van $15 \mathrm{vc}$ tot $50 \mathrm{nC}$, en die Vierde styl vanaf $50 \mathrm{nC}$ (Beard \& Henderson 2001:38-39). Alhoewel kunstenaars gedurende die Tweede styl nog nie die tegniek van perspektief bemeester het nie, is metodes ontwikkel om 'n illusie van diepte te skep, veral in kleiner en donkerder vertrekke. Die interieur is op 'n unieke wyse met deurlopende temas, verskillende samestellings, versierings en kleure verfraai. Die friesrand is in verskillende panele (pinakes) verdeel en argitektonies omraam. Hierdie verlies van ware styl ten gunste van oppervlakkige versiering met geverfde pilasters, argitrawe en fasades, is omstreeks die begin van Octavianus se magsoorname hewig deur die argitek Vitruvius Pollio, De Architectura 8 gekritiseer (Ellis 2000:14).

35 Rekonstruksie van triclinia in Pompeii dui daarop dat hierdie vertrekke gewoonlik min of geen vensters gehad nie en gevolglik baie donker was. Natuurlike lig was slegs van die wye voordeur afkomstig. Ook cubicula, waarvan die besondere klein formaat op slaapvertrekke dui, was donker vanweë die afwesigheid van vensters en die besondere smal gange (Ellis 2000:150-51). 
aspek wat Lucretius aanraak in DRN 2.798: qualis enim caecis poterit color esse tenebris? ('want watter kleur sal daar in stikdonkerte kan wees?').

Die Romeine was ook van kers-, lamp- of fakkellig afhanklik en het daagliks die wisselwerking tussen lig en donkerte ervaar. Die uitwerking van hierdie flikkerende lig op verskillende kleure en die gevolglike glans wat so sou kon ontstaan, was 'n ander faset wat vir die Romeine belangrik was. ${ }^{36}$ Dit is moontlik dat die glans wat met Tiriese purper (purpura) verbind is, die populariteit van hierdie kleurstof verseker het, en waarskynlik as rede voorgehou word vir die gebruik daarvan wat van oudsher so sterk in Rome gevestig was (Plinius Maior, HN 9.136: purpurae usum Romae semper fuisse video). Kleedstowwe van purper is as vertoonstukke van status en welvaart (beide amptelik vir staats- en godsdienstige seremonies én privaat) beskou.

\section{Kleur in die Romeinse letterkunde}

Romeinse skrywers het gepoog om aan alles wat hulle waargeneem het, en met die woorde tot hulle beskikking, uitdrukking te gee. Weens die beperkte omvang van hul kleurterminologie het hulle óf kleurwoorde geskep, ${ }^{37}$ of uitbeeldings met omskrywing aangevul. ${ }^{38}$ Daar is ook verklarings gesoek om 'visie' as ervaring verstaanbaar te maak. Dit het teorieë soos dié van Lucretius (94-55 vC) opgelewer op 'n stadium toe die filosofiese middelpunt van Griekeland na Italië verskuif het. Die intelligentsia van Rome is beïnvloed deur die $\mathrm{Ou}$ en Nuwe Akademie, Pythagoreïsme, Peripatetiese filosofie, Stoïsisme, Epikurisme en Skeptisisme. Lucretius se De Rerum Natura kan dus as die uitvloeisel van Griekse en

36 Volgens Gottschalk 1964:82-85 was Theophrastus, skrywer van De Sensibus, ook die outeur, of moontlike dryfveer, van De Coloribus. Volgens 3.793b.20 is kleur nooit suiwer nie, maar wissel kleure namate dit in die lig van 'n vuur, die maan of by kerslig waargeneem word. Ook Lucretius verwys na die belangrikheid van lig op kleurwaarneming: Die hoek waarmee lig op die voorwerp val, beïnvloed die waarneming van 'n spesifieke kleur, uiteengesit in DRN 2.799-800: lumine quin ipso mutatur propterea quod / recta aut obliqua percussus luce refulget ('[kleur] word immers deur lig self verander, in die mate waarin glans deur die impak van 'n direkte of skuins ligstraal weerkaats word').

37 André 1949:382-84 bied 'n kort samevatting van verskeie kleurterme met hul (waarskynlik) eerste gebruik.

38 By gebrek aan 'n geskikte kleurwoord omskryf Vergilius in Geo. 4.274-75 die besondere skakering van die blomblare: aureus ipse, sed in foliis, quae plurima circum / funduntur, violae sublucet purpura nigrae ("[die kern van die blom] self is 'n goudgeel, maar op die blomblare wat weelderig daarom uitgroei, glinster die purper van die donker "viooltjie" daaronder'). Die verskillende kleurwaardes dra tot 'n aanskoulike kleurkontras by van 'n glansende (sublucet) donker-purper en goudgeel. 
Hellenistiese teorieë oor kleurpersepsie beskou word. ${ }^{39}$ Sy bespreking van kleur in die tweede helfte van Boek 2 volg op sy breedvoerige uiteensetting van die verskillende vorme en werking van atome, wat verskillende spesies en kwaliteite (eventa) soos kleure, smake en reuke insluit. In reëls 661-99 toon die digter hoe atome die sintuie op verskillende wyses beïnvloed, wat as verklaring dien vir hul verskillende vorme (Bradley 2011:74-75). Lucretius ontleed al die kwaliteite wat deur die sintuie waargeneem word afsonderlik, en in reëls 730-841 word kleur as die belangrikste van hierdie komponente voorgehou en in groot detail ontleed.

Geen bespreking van kleur in antieke Rome kan Aulus Gellius ( $c a$. 123-165 nC) se Noctes Atticae 2.26 verontagsaam nie. Hy ondersoek 'n wye verskeidenheid van onderwerpe, wat op die kultuurlewe van Rome gedurende die middel van die tweede eeu $\mathrm{nC}$ fokus. In 'n waarskynlik fiktiewe debat tussen die flambojante orator, die Grieks gesinde eunug, Favorinus, en sy sosiale teenbeeld, M Cornelius Fronto, 'n oud-konsul en Marcus Aurelius se Latynse leermeester, word die verskille tussen Latynse en Griekse kleurwoorde uitgespel. Volgens Favorinus is die omvang van antieke Griekse kleurwoorde wyer as dié van Latyn, maar Fronto oortuig hom dat Latyn ryker is aan sekere kleurnuanses. ${ }^{40}$ Daar word tussen tipes kleur (genera) en kleurkategorieë (vocabula) onderskei. 'n Aspek wat ook aangeraak is, is die mens se vermoë om meer afsonderlike kleure waar te neem, as waaraan hy uitdrukking kan gee (multiplex colorum facies, appellationes autem incertae et exiguae).

Anders as in die Oudheid, lewer moderne chemiese kleurprosesse telkens dieselfde resultate op, sodat die moderne kleurspektrum meer as 'n duisend kleure insluit. Gevolglik kom dit vir ons vreemd voor dat verskeie Latynse kleurterme met 'n wye reeks van kleurwaardes vereenselwig kan word. So byvoorbeeld kan die kleurwaardes van purpura en purpureus van purper tot bloedrooi en selfs donkerviolet wissel. Om die verwarring te vereger, kan die betekenismoontlikheid 'glansend' ook met hierdie kleurterm vereenselwig word. Dieselfde geld ook vir die term croceus, waarvan die kleurwaardes van geel tot helder skarlakenrooi kan wissel (Vels Heijn 1951:45), ook geel met oranje ondertone en selfs 'n rooierige oranje (Sebesta \& Bonfante 1994:68). Word luteus met ligroos of geel vereenselwig? (Edgeworth 1992:255-65) Vir ons is dit onverstaanbaar dat al die uiteenlopende betekenismoontlikhede met 'n enkele kleurwoord verbind word. Tog moet hierdie verskynsels geensins gesien word as Romeine se onvermoë om

39 Sien Baran \& Chisleag 1968: 'Lucréce, le premier, a compris la valeur chromatique des mots et leur a donné un sens esthétique ('Lucretius was die eerste persoon om chromatiese waarde aan woorde te gee en estetiese waarde daaraan toe te voeg').

40 Hierdie klassieke debat dien as verwysingsraamwerk vir hedendaagse navorsing oor antieke kleurkategorieë, wat dié van Eco 1985:157-75 insluit. Dit is baie opvallend dat André 1949 geensins na Gellius verwys nie. 
'korrek' tussen kleurwaardes te onderskei nie. In realiteit was die uiteenlopende kleure (en gevolglik ook die betekenismoontlikhede) wat met hierdie kleurterme verbind was, die eindproduk van uitgerekte en ingewikkelde kleurprosesse, wat ongetwyfeld vanweë die onbestendigheid van Romeinse tegnieke en onsuiwer kleurstowwe verskillende kleurskakerings opgelewer het.

\section{Navorsing oor Romeinse kleurgebruik}

Die Franse filoloog, André het reeds in 1949 'n baie omvattende oorsig oor die gebruik van kleurwoorde in die Romeinse letterkunde gepubliseer. Terme word in kleurgroepe of -families gerangskik (le blanc, le noir, le gris, le rouge, le brun, le jaune, le bleu, le vert, le violet) om die presiese nuanses volgens moderne ekwivalente vas te pen, 'n benadering wat Bradley (2011:12) fel kritiseer. ${ }^{41}$ André het ook die inherente simboliek van kleure en die persoonlikheid van 'n skrywer ontleed, en dit aan die hand van sy keuse en gebruik van kleurwoorde. Kort op sy hakke het die semantiese ondersoek van Vels Heijn (1951) gevolg, wat kleurwoorde in Romeinse prosa en poësie nagevors het en met Griekse ekwivalente vergelyk het. Anders as André, het hy kleurterme in slegs drie groepe verdeel: geel-rooi, groen-blou en wit-swart (wat ook grys insluit). Melding moet ook gemaak word van die bydrae van Stearn (2004), veral sy handige hoofstukke XVIII (229-51) en XIX (252-74), waarin Romeinse en Griekse kleurterme onderskeidelik gedetailleerd uiteengesit is. Hy het die kleurbasis verbreed met die toedeling van verskillende tinte om sodoende groter presisie aan die Latynse terme te gee. Hiervolgens kan 'n term vir wit, wat byvoorbeeld met albus aangedui is, nou met niveus as 'sneeuwit', candidus as 'suiwer wit' of eburneus as 'ivoorwit' verfyn word. $^{42}$

${ }^{41}$ Volgens Bradley forseer André die assosiasie van Latynse kleurterme met hul naaste moderne ekwivalente. Ook word die semantiese omvang van 'n kleurkategorie oorvereenvoudig deur die skep van onder-afdelings om verskillende skakerings en tinte in te sluit.

42 Tot dusver in die een-en-twintigste eeu was die belangstelling in die antieke kleurterminologie heel beskeie, met slegs 'n paar interdissiplinêre konferensies wat publikasies opgelewer het: MA Tiverios \& DS Tsiafakis (reds), Color in ancient Greek (Thessalonika, April 2000), Thessalonika 2002; S Beta \& MM Sassi (reds), I colori nel mondo antico (Siëna, Maart 2001), Fiesole 2003; en K Stears \& L Cleland (reds), Colours in the ancient Mediterranean World (Edinburgh, September 2001), Oxford 2004.

Die volgende afsonderlike publikasies het die lig gesien: A Dubel, V Naas \& A Rouveret (reds), Couleurs et matières dans l'Antiquité: textes, techniques et pratiques (2006); M Pastoureau, Blue. The history of a colour (2001), en Black. The history of a colour (2008), en Green. The history of a colour (2014). Sien ook die gesaghebbende werke van M Bradley, Colour and meaning in ancient Rome (2011) en A Grand- 
Sou die kollig (byvoorbeeld) na Vergilius verskuif, is die omvang van navorsing karig. Price (1883) publiseer 'n artikel oor die kleursisteem van hierdie digter, waarvolgens hy skynbaar 'warm' kleure bo 'koue' kleure verkies. Hy staaf sy bevindings met kwantitatiewe data, maar laat na om aan te dui op watter werk(e) van Vergilius sy bevindings gefundeer is. Turnbull (1946) verwys na Vergilius as die 'skilder-digter', daar sy implementering van lyn, kleur, vorm en die kontras van kleure en teksture op die basiese beginsels van skilderwerk dui. Benewens die (soms terloopse) verwysings na kleurwoorde in die kommentare van sommige kritici (Conington [1881], Page [1968], Williams [1979], Thomas [1988], Mynors [1990] en Erren [2003]) het Edgeworth (1992) se literêr-kritiese studie oor Vergilius se gebruik van kleurterme in die Aeneïs baie van die reeds snuifgetrapte onsekerhede ter syde gestel. ${ }^{43}$ Hy kom tot die gevolgtrekking dat'n gebrek aan insig van en waardering vir hierdie besondere aspek van die digter se kreatiewe vermoëns verreikend is: 'Without an understanding of Vergil's color strategies, our appreciation of the Aeneid is incomplete ... The Aeneid will not be fully understood ... until its readers acknowledge and understand it as a sensual poem' ${ }^{44}$ In sy kort samevatting oor die kleurgebruik van Vergilius se voorgangers, tydgenote en opvolgers, kom Edgeworth $(1992: 1-17,60)$ tot die gevolgtrekking dat geen ander Romeinse digter kleur met soveel vaardigheid en so suksesvol as Vergilius gebruik nie. Clarke (2003) weerlê egter hierdie siening in 'n soortgelyk

Clément, La fabrique de couleurs. Histoire du paysage (2011). Die monografie van RB Goldman, Color-terms in social and cultural context in ancient Rome (2013) is egter onbevredigend, soos Wharton (2014) ook aandui.

43 Om groter presisie aan sy navorsing te verleen, identifiseer Edgeworth ses belangrike wyses waarop kleurterme in poësie aangewend kan word:

- Formulêr: Kleurwoorde vorm deel van formulae wat terugverwys na voorgangers, alhoewel hierdie frases dikwels aangepas of innoverend gebruik word.

- Funksioneel: Die kleurwoord vorm 'n integrale deel van die teks.

- Verwysend of sinspelend: Die kleurgebruik van 'n vroeëre skrywer word intertekstueel herhaal.

- Dekoratief: Die term vorm deel van 'n treffende uitbeelding.

- Kumulatief: Groeperings van drie of vier kleurterme volg mekaar vinnig op, gewoonlik in die klimaks van die gedig wat spanning kan ontlaai.

- Geassosieerd of tematies: Kleurterme word herhaaldelik gebruik en sulke kleurgroepe (byvoorbeeld wit en groen) verbind tonele tematies.

44 Clarke 1994:2-3 beskou Edgeworth se analise van die tematiese gebruik van kleurgroepe as besonder geslaag, wat Harrison 1994:278 egter bevraagteken. Hy betreur die gebrek aan etimologiese definisie wat die onderskeid tussen kleurwoorde (soos dié tussen ater en niger) sou kon verklaar. Putnam 1993:70 kritiseer Edgeworth se lemma van purpureus en die weglating van implisiete kleurgebruik, wat woorde soos columba en gramen sou insluit. Sien ook Biggam 2012:193-94 se besonder gunstige evaluering van Edgeworth se bydrae in die lig van haar navorsing oor die potensiaal van 'toegepaste historiese kleur-semantiek'. 
studie oor die kleurgebruik van die liriese en elegiese digters Catullus, Propertius en Horatius (tot sy Carmina beperk). Deels volgens Edgeworth se metode en met gebruikmaking van 'n kleurkonkordans vors Clarke elke gebruik van 'n aantal kleurterme in hierdie digters na, mits hulle in die gesaghebbende werk van André (1949) opgeneem is. Soos Edgeworth, fokus sy ook op kleurgroepe waar twee of meer kleurterme mekaar komplementeer of kontrasteer. Arkins (2003:379) loof Clarke se belangrike toevoeging tot die algemene studie van kleurgebruik, en veral haar beklemtoning van woorde wat 'glans' aandui, 'n aspek van die digkuns wat tot nou toe grootliks agterweë gebly het.

\section{Laaste dekades van die twintigste eeu}

Die mening is lank gehuldig dat basiese kleurbegrippe nie tussen tale oordraagbaar is nie en dat elke taal uitdrukking aan kleurwaarneming met arbitrêre kleurterme weergee. Besprekings en navorsing is vanuit verskeie hoeke benader wat wetenskaplike, kunshistoriese, ${ }^{45}$ linguistiese, psigologiese, psigofisiologiese ${ }^{46}$ en antropologiese benaderings ingesluit het. Die leerstelling van Whorf(-Sapir) die teorie van linguistieke relatiwiteit - is deur die antropoloog, Brent Berlin, en die taalkundige, Paul Kay, in hul seminale Basic color terms (1969) weerlê. Hulle grond hul bevindinge op 'n evolusionêre hipotese en universele sisteem van kleuronderskeid aan die hand van kulturele ontwikkeling, waarvolgens wit en swart as 'basies' beskou word en in alle tale voorkom. Ook kan daar tot elf basiese kleurkategorieë in 'n taal aanwesig wees, wat kumulatief en progressief (van die basiese wit en swart) volgens die taal se ontwikkeling bygevoeg word. ${ }^{47}$ Hierdie

45 Sien onder andere J Gage se seminale Colour and culture (1993) en die korter Colour and meaning (1999) wat die geskiedenis van kleur vanaf Klassieke Griekeland tot die twintigste eeu toelig, veral vanuit 'n kunshistoriese perspektief.

46 Volgens Ratliff 1976:311-30 moet daar 'n sekere psigofisiologiese 'ontvanklikheid' teenwoordig wees, wat die aard en ontwikkeling van kleurterminologie in enige taal bepaal.

47 Berlin \& Kay fundeer hulle teorie op die volgende fases:

Fase 1: $\quad$ Alle tale met slegs twee basiese kleurterme bevat woorde vir swart en wit.

Fase 2: $\quad$ Tale met slegs drie kleurwoorde sluit terme vir swart, wit en rooi in.

Fases 3\&4: Ingesluit by swart, wit en rooi volg òf groen en geel, ò geel en groen (in enige van die volgordes).

Fase 5: $\quad$ Saam met die vorige vyf terme kom blou voor.

Fase 6: $\quad$ By die voorafgaande word bruin as 'n sewende kleur gevoeg.

Fase 7: Laastens volg pers, rooskleurig, oranje en grys, in geen spesifieke volgorde nie.

Sien Biggam 2012, veral hoofstuk 2, vir 'n gedetailleerde uiteensetting van hierdie sisteem. 
bevindinge is in die algemeen aanvaar, alhoewel die aanvanklike kritiek meestal op hul metodiek gerig was (Ratliff 1976:311-12). Die snydendste kritiek het later op hul Anglosentriese benadering gefokus waarvolgens 'n Westerse model van kleurbeskrywing op nie-Westerse sprekers afgedwing sou word, wat weer eens verwarring sou skep en tot wanvoorstellings sou lei. Volgens Witzel (2008) voldoen alle tale ook nie aan die voorgestelde elf basiese kleurterme nie. So byvoorbeeld het Russies 'n bykomende kleurwoord wat tussen 'ligblou' en 'donkerblou' onderskei, terwyl Koreaans vyftien basiese kleurterme insluit. Ander tale kombineer 'blou' en 'groen' as een kleurwoord, in Engels bekend as 'grue' en as 'glas' in Wallies en Iers. By sekere taalgebruikers is kleurskakering die deurslaggewende faktor, terwyl helderheid en glans weer vir ander belangriker is. $^{48}$

Dit bring ons terug by Pastoureau (2001:8) se identifisering van kleur as 'n komplekse sosiale konsep. Dit toon ook die fyn lyn tussen die fisiese gewaarwording en die vermoë van taal om die visuele te omskryf. Dit vereis 'n besondere mate van sensitiwiteit wat in alle filosofiese en literêre besprekings van kleurpersepsie teenwoordig moet wees, uiteraard ook in die ontleding en interpretasie van alle kleurterme. Aldus kan daar nou groter begrip wees vir

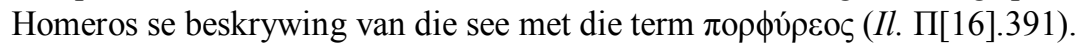

\section{BIBLIOGRAFIE}

André, J 1949. Étude sur les termes de couleur dans la langue latine. Parys: Librairie C Klinsieck.

Arkins, B 2003. Poetic colouring. Resensie van J Clarke, Imagery of colour and shining in Catullus, Propertius \& Horace. CR 54.2:378-80.

$\mathrm{Na}$ afloop van die 1992 Asilomar-konferensie in Kalifornië, verskyn Color categories in thought and language, saamgestel deur die filosoof, C L Hardin. Dit bevat onder andere Kay, Berlin, Maffi \& Merrifield se artikel 'Color naming across languages' wat die data van hul navorsing insluit. Hardin \& Maffi (1997:21, met verwysing na die eksperimentele werk van Rosch) ontleed bykomende empiriese bevindings en teoretiese interpretasies, wat onder andere die twee-term sisteem van fase 1 (swart en wit, of eerder donker en lig) herstruktureer. Dit is aangepas tot net een term wat wit, rooi en geel insluit en 'n ander term vir swart, blou en groen. Dit kom neer op 'n kategorie vir wit plus 'warm' kleure, in kontras met een vir swart plus 'koel' kleure. In die afgelope dekades is bykomende gedetailleerde formulering by bostaande bevindings gevoeg, en in Julie 2009 verskyn Berlin \& Kay se opvolg, The world color survey, wat deur CLSI (The Center for the study of language and information), Stanford, gepubliseer is.

48 Sien Casson 1997:224-238 se gedetailleerde bespreking: 'Color shift: Evolution of English color terms from brightness to hue'. 
Baran, N \& Chisleag, M 1968. Éléments chromatiques chez Lucrèce. REL 46:14569.

Beard, M \& Henderson, J 2001. Classical art: From Greece to Rome. Oxford: Oxford University Press.

Berlin, B \& Kay, P 1969. Basic color terms: Their universality and evolution. Berkeley: University of California Press.

Biggam, C P 2012. The semantics of colour: A historical approach. Cambridge: Cambridge University Press.

Bradley, M 2006. Resensie van L Villard, Couleurs et vision dans l'antiquité classique. BMCR 2006.08.47

— 2011. Colour and meaning in ancient Rome. Cambridge: Cambridge University Press.

Casson, R W 1997. Color shift: Evolution of English color terms from brightness to hue. In Hardin, C L \& Maffi, L (reds), Color categories in thought and language, 224-39. Cambridge: Cambridge University Press.

Clarke, J M 1994. Resensie van R J Edgeworth, The colors of the Aeneid. Electronic Antiquities Oktober volume II.3.

— 2003. Imagery of colour and shining in Catullus, Propertius \& Horace. New York: Peter Lang.

Clarke, M 2004. The semantics of colour in the early Greek word-hoard. In Cleland, L \& Stears, K (reds), Colour in the ancient Mediterranean world, 131-39. Oxford: Hadrian Books.

Cleland, L \& Stears, K (reds), 2004. Colour in the ancient Mediterranean world. Oxford: Hadrian Books.

Cobley, P (red) 1996. The communication theory reader. New York, NY: Routledge.

Deacy, S \& Villing, A 2004. Athena blues? Color and divinity in ancient Greece. In Cleland, L \& Stears, K (reds), Colour in the ancient Mediterranean world, 85-90. Oxford: Hadrian Books

D’Hérouville, P 1930. À la campagne avec Virgile. Parys: Société d'Édition 'Les Belles Lettres'.

Eco, U 1985. How culture conditions the colours we see. In M Blonsky (red.), On signs, 157-75. Oxford.

- 1996. How culture conditions the colours we see. In Cobley, P (red), The communication theory reader, 148-71. New York, NY: Routledge.

Edgeworth, R J 1992. The colors of the Aeneid. New York: Peter Lang.

Ellis, S P 2000. Roman housing. Londen: Duckworth.

Gibson, J 1968. The senses considered as perceptual systems. Londen: Allen \& Unwin. 
Gladstone, W E, 1858. Homer's perception and use of colour. In Studies on Homer and the Homeric Age. Volume 3, 456-99. Oxford.

1877. The colour sense. Nineteenth century 2:366-88.

Goetz, K E 1905 \& 1908. Waren die Römer blaublind? In Archiv für lateinische Lexikographie und Gramatik 14:75-88; 15:527-47.

Gottschalk, H 1964. The De coloribus and its author. Hermes 92:59-85.

Hardin, C L \& Maffi, L (reds), 1997. Color categories in thought and language. Cambridge: Cambridge University Press.

Harrison, S J 1994. Colouring the Aeneid. Resensie van R J Edgeworth, The colors of the Aeneid. CR 4:277-78.

Irwin, E 1974. Colour terms in Greek poetry. Toronto: A M Hakkert Ltd.

Keller, H 1910. Analogies in sense perception. In The world I live in, 105. New York: Century Co.

Kenny, A 1999. Descartes the dualist. Ratio 12:114-27.

Kober, A E 1932. The use of color words in the Greek poets. Genève: Humphrey Press.

Lilja, S 1972. The treatment of odours in the poetry of Antiquity. Helsinki: Societas Scientiarum Fennica.

Maxwell-Stuart, P G 1981a. Studies in Greek Colour Terminology. Volume I. ГАAYKO $\Sigma$. Leiden: E J Brill.

— 1981b. Studies in Greek Colour Terminology. Volume II. ХАРОПОГ. Leiden: E J Brill.

Osborne, H 1968. Colour concepts of the ancient Greeks. Brit J Aesthetics 8.3:26983.

Østergaard, J S 2008. Emerging colors: Roman sculptural polychromy revived. In Panzanelli, R (red), The colour of life: Polychromy in sculpture from antiquity to the present, 43-62. Malibu: Paul Getty Publications.

Pastoureau, M 2001. Blue. The history of a colour. Princeton University Press.

Pentak, S \& Roth R 2004. Color basics. Belmont, CA: Thomson / Wadsworth. Platnauer, M 1921. Greek colour-perception. CQ 15:153-62.

Price, T R 1883. The color-system of Vergil. The American Journal of Philology 4.1:1-20.

Putnam, M C J 1993. Resensie van R J Edgeworth, The colors of the Aeneid. Vergilius 39:69-73.

Ratliff, F 1976. On the psychophysiological bases of the universal color terms. PAPS, 120.5:311-30.

Ruscillo, D 2007. Resensie van Cleland, L et al. (reds), Colour in the ancient Mediterranean. American Journal of Archaeology 111.2:371-73. 
Sivik, L 1997. Color systems for cognitive research. In Hardin, C L \& Maffi, L (reds), Color categories in thought and language, 163-93. Cambridge: Cambridge University Press.

Skard, S 1946. The use of colour in literature. PAPS 90:163-249.

Stearn, W T 2004. Botanical Latin. Portland, Ore: Timber Press.

Turnbull, P 1946. Vergil: Painter with words. CJ 42.2:97-101.

Van Leeuwen, $\mathrm{T}$ 2011. The language of colour: An introduction. Londen \& New York: Routledge.

Vels Heijn, N 1951. Kleurnamen en kleurbegrippen bij de Romeinen. Utrecht: Drukkerij v/h Kemink en Zoon N.V.

Wallace, F E 1927. Color in Homer and ancient art: Preliminary studies. Smith College Classical Studies.

Wharton, D 2014. Resensie van R B Goldman, Color-terms in social and cultural context in ancient Rome. CJ-Online 2014.09.15.

Wierzbicka, A 2006. The semantics of colour - A new paradigm. In Biggam, C P \& Kay, C J (reds), Progress in colour studies, volume 1. Language and culture, 1-24. Amsterdam: Benjamins.

Witzel, C 2008. Color naming.

Beskikbaar: http://www.allpsych.uni-giessen.de/chris/ 2016, September 15.

Young, D 1964. The Greeks' colour sense. Review of the Society for Hellenic Travel 4:42-46.

Zanker, P 1988. The power of images in the age of Augustus. Ann Arbor: University of Michigan Press.

Zink, S 2008. Reconstructing the Palatine temple of Apollo. JRA 21:47-63.

Zink, S \& Piening, H 2009. Haec aurea templa: The Palatine temple of Apollo and its polychromy. JRA 22:109-22. 